\title{
UJI AKTIVITAS ANTIOKSIDAN KRIM EKSTRAK DAUN MENGKUDU ( Morinda citrifolia L.) BERBASIS VANISHING CREAM
}

\author{
Dessy Erliani Mugita Sari*1, Thessa Happy Ernanda ${ }^{2}$ \\ Program Studi Farmasi, Sekolah Tinggi Ilmu Kesehatan Cendekia Utama Kudus \\ e-mail : ${ }^{* 1}$ dessyerliani1@gmail.com, ${ }^{2}$ Ernandathessa@gmail.com
}

\begin{abstract}
ABSTRAK
Daun mengkudu (Morinda citrifolia L.) adalah sumber antioksidan alami karena mengandung senyawa fenol dan flavonoid. Daun mengkudu di ekstrak secara maserasi dengan pelarut etanol 96\%. Dalam penelitian eksperimental ini dilakukan pembuatan krim ekstrak daun mengkudu, pengujian aktivitas antioksidan dengan uji penangkapan radikal DPPH (2,2-di(4-tert-octylphenyl)1-picryl-Hydrazyl) dengan menggunakan spekrofotometri Uv-Vis dan uji parameter sifat fisik krim ekstrak daun mengkudu. Krim ekstrak daun mengkudu dengan basis Vanishing Cream diformulasikan menjadi tiga formulasi, dengan variasi konsentrasi ekstrak sebanyak 5\%, 10\%, 15\%. Uji sifat fisik krim meliputi uji organoleptis, uji homogenitas, uji pH, uji daya sebar dan uji daya lekat. Kadar total fenol 64,9mgGAE/g, dan kadar total flavonoid 0,21\% $\mathrm{mg} / \mathrm{QE} / \mathrm{g}$, antioksidan ekstrak daun mengkudu diperoleh hasil 137/527 $\mathrm{\mu g} / \mathrm{ml}$, aktivitas antioksidan krim daun mengkudu IC50 pada FI (5\%) 124,724, FII (10\%) 123,333, FIII (15\%) 121,286. Krim ekstrak etanol daun mengkudu didapatkan hasil yang baik, memenuhi syarat, SNI, dan kriteria yang baik. Aktivitas antioksidan nilai IC50 formula yang lebih baik yaitu Formula III (15\%) 121,286 yang artinya mempunyai aktivitas antioksidan sedang.
\end{abstract}

Kata kunci: Daun Mengkudu (Morinda citrifolia L.), DPPH, radikal bebas, antioksidan.

\begin{abstract}
Noni leaf (Morinda citrifolia L.) is a source of natural antioxidants because it contains phenolic compounds and flavonoids. Noni leaves were extracted by maceration with $96 \%$ ethanol as solvent. In this experimental study, noni leaf extract cream was made, antioxidant activity was tested by DPPH radical scavenging test (2,2-di(4-tert-octylphenyl)1-picryl-Hydrazyl) using UV-Vis spectrophotometry and physical properties parameter test of cream. noni leaf extract. Noni leaf extract cream based on Vanishing Cream was formulated into three formulations, with various extract concentrations of 5\%, 10\%, 15\%. The physical properties test of the cream includes organoleptic test, homogeneity test, $p H$ test, dispersibility test and adhesion test. Total phenol content $64.9 \mathrm{mg} G A E / g$, and total flavonoid content $0.21 \% \mathrm{mg} / \mathrm{QE} / \mathrm{g}$, antioxidant noni leaf extract obtained $137 / 527 \mathrm{~g} / \mathrm{ml}$, antioxidant activity of noni leaf cream IC50 at FI (5\%) 124,724, FII (10\%) 123,333, FIII (15\%) 121,286. Noni leaf ethanol extract cream obtained good results, met the requirements, SNI, and good criteria. The antioxidant activity of the better formula IC50 value is Formula III (15\%) 121,286 which means it has moderate antioxidant activity.
\end{abstract}

Keywords: Noni leaf (Morinda citrifolia L.), DPPH, free radicals, antioxidants.

\section{PENDAHULUAN}

Organ terluar dari tubuh makhluk hidup yang berfungsi melindungi tubuh dari luar adalah kulit [1]. Kerusakan kulit dapat mengganggu kesehatan manusia serta penampilan oleh karena itu kulit perlu dilindungi kesehatannya dan dijaga. Penyebab kerusakan kulit yang paling utama adalah radikal bebas [1].

Radikal bebas sangat bersifat reaktif, serta jika jumlahnya tidak berlebihan di dalam tubuh manusia bisa diatasi keberadaannya. Antioksidan ditingkat sel, membran dan ekstra sel berasal dari radikal bebas yang digunakan sebagai pertahanan tubuh di beberapa mekanisme sel [2].

Antioksidan adalah inhibitor yang bekerja menghambat oksidasi dengan cara bereaksi dengan radikal bebas reaktif membentuk radikal bebas tak reaktif yang realatif stabil. Antioksidan yang dihasilkan di tubuh manusia jumlahnya tidak dapat mencukupi untuk mengatasi adanya 
radikal bebas oleh karena itu tubuh perlu penambahan asupan antioksidan dari luar tubuh baik berupa vitamin atau makanan [3].

Senyawa flavonoid merupakan salah satu senyawa metabolit sekunder yang ada didalam tumbuhan yang mempunyai aktivitas antiksidan. Sekarang ini bahan antioksidan yang berasal dari tanaman lebih diminati, yang mana diyakini memiliki efek samping yang lebih aman dibandingkan dengan yang berasal dari bahan kimia atau sintetik. Salah satu jenis tanaman yang telah dikenal berbagai manfaat dan khasiatnya adalah daun mengkudu (Morinda citrifolia L) [4].

Kandungan senyawa metabolit daun mengkudu yaitu senyawa alkaloid, coumarin, flavonoid, saponin, tannin,steroid dan triterpenoids memiliki aktivitas antioksidan yang dapat melawan radikal bebas [5] Senyawa yang diduga memiliki peran paling besar di dalam tanaman sebagai antioksidan adalah flavonoid [6].

Sediaan kosmetik yang banyak tersedia dipasaran dan diminati oleh konsumen adalah bentuk sediaan krim karena banyak keuntunganya salah satunya adalah mudah dalam pengaplikasiannya di kulit, lebih nyaman digunakan pada wajah, dapat dicuci dengan air [7]. Dengan demikian ekstrak daun mengkudu sangat berpotensi untuk diformulasi menjadi krim antioksidan.

\subsection{Alat dan Bahan}

\section{METODE PENELITIAN}

Alat-alat yang digunakan dalam penelitian ini adalah peralatan gelas ukur, labu takar, blender, kertas saring, corong kaca, mikropipet, pipet tetes, flacon, beaker glass, batang pengaduk, mortar, stamper, sendok tanduk, timbangan analitik, rotary evaporator Eyela N-1000, spatula, spektrofotometer UV-Vis, waterbath, pot salep, sudip. Bahan yang digunakan adalah ekstrak daun mengkudu setengah tua, bahan yang digunakan pada pengujian total fenol dan flavonoid adalah asam galat, reagen folin ciocalteu, natrium karbonat, larutan kuersetin, $\mathrm{AlCl}_{3}$, etanol pro analis, dan DPPH.

Bahan yang digunakan pada formulasi krim adalah ektrak daun mengkudu, asam stearat, setil alcohol, metil paraben, sorbitan monostearat, propil paraben, larutan sorbitol 70\%, polisorbat 60 , aquades

\subsection{Jalannya Penelitian}

\section{a. Determinasi Tanaman}

Determinasi daun mengkudu dapat dilakukan dengan menyesuaikan ciri morfologi dari tanaman mengkudu yang telah dibuktikan di Laboratorium.

\section{b. Pembuatan Simplisia}

Simplisia diolah dengan tahapan pengumpulan dan pengolahan daun mengkudu yang meliputi sortasi basah, pencucian, parajangan, pengeringan, sortasi kering dan pembuatan serbuk simplisia.

\section{c. Pembuatan Esktrak}

Menimbang serbuk daun mengkudu lalu dimasukkan kedalam botol gelap ditambahkan pelarut etanol 96\% dan direndam selama 3x24 jam sambil sesekali diaduk. Hasil maserat disaring dengan menggunakan kertas saring dan ampasnya dilakukan remaserasi kembali dengan pelarut yang sama. Maserat dipekatkan diatas waterbath hingga diperoleh ekstrak kental.

\section{d. Uji Total Fenol dan Flavonoid}

Pada uji total fenol ditentukan dengan metode folin ciocalteu digunakan asam galat sebagai standarnya, kemudian dibuat seri konsentrasi 20,25,30,35,40,45 untuk kurva bakunya. Direaksikan dengan folin ciocalteu pada rentang operating time dan dibaca pada panjang gelombang 600-800 $\mathrm{nm}$. Begitu juga dengan sampel direaksikan dengan folin ciocalteu dan $\mathrm{Na}_{2} \mathrm{CO} 37,5 \%$ setelah itu diamkan pada OT dan dibaca pada panjang gelombang yang diperoleh yaitu $760 \mathrm{~nm}$ dengan spektrofotometri Uv-vis. Kandungan total fenol dinyatakan sebagai mg/g ekuivalen asam galat. 
Pada uji total flavonoid kuersetin sebagai larutan standarnya, kemudian dibuat seri konsentrasi 3, 4, 5, 6, 7, 8, 9 untuk kurva bakunya, kemudian direaksikan dengan $\mathrm{AlCl}_{3}$ dan didiamkan selama operating time dan baca pada panjang gelombang 400-800 nm. Begitu juga dengan sampel direaksikan dengan $\mathrm{AlCl}_{3}$ didiamkan selmaa OT dan baca pada panjang gelombang yang diperoleh yaitu $425 \mathrm{~nm}$ dengan menggunakan spektrofotometri Uv-vis.

e. Uji Aktivitas Antioksidan Ekstrak dan Krim Daun Mengkudu

1) Pembuatan seri konsentrasi kuersetin

Menimbang kuersetin sebanyak $50 \mathrm{mg}$, kemudian dilarutkan dalam etanol p.a hingga 50 ml. Diperoleh larutan stok 1000ppm, dan dibuat seri konsentrasi 1, 2, 3, 4, dan 5.

\section{2) Pembuatan Seri Larutan Uji Ekstrak Dan Krim Daun Mengkudu}

Sebanyak 50 mg ekstrak dan krim daun mengkudu dilarutkan dalam etanol p.a hingga 50 $\mathrm{mL}$, diperoleh larutan stok 1000 ppm. Dibuat seri konsentrasi 50,75,100,125,dan150. Sebanyak $10 \mathrm{~mL}$.

\section{3) Penentuan operating time dan panjang gelombang maksimum}

Dilakukan dengan cara mengambil 0,2 kuersetin ditambahkan 3,8 $\mu \mathrm{L}$ DPPH, kemudian dibaca absorbansinya setiap 5 menit pada $\lambda$ maksimum yang telah diproleh. Waktu pengikatan DPPH yang paling stabil merupakan operating time. Kemudian mengkur panjang gelombang maksimum dengan sepektrofotometri UV-vis pada panjang gelombang 500-525 nm. Untuk mendapatkan absorbansi $\pm 0,2-0,8$. Panjang gelombang yang dihasilkan paling besar merupakan panjang gelombang yang maksimal.

\section{4) Uji Aktivitas Antioksidan Krim dan Ekstrak Daun Mengkudu}

Menimbang ekstrak dan krim sebanyak 50mg dilarutkan dengan etanol p.a $50 \mathrm{~mL}$. Dibuat seri konsentrasi 50,75,100,125, 150 sebanyak 10ml. Kemudian ditambahkan 3,8 $\mu \mathrm{L}$ DPPH dan didiamkan ditempat yang gelap selama 30 menit. Dibaca absorbansinya menggunakan spektrofotometri UV-vis pada panjang gelombang yang diperoleh yaitu $517 \mathrm{~nm}$. Dihitung \% inhibisi dan $\mathrm{IC}_{50}$ ekstrak dan krim daun mengkudu.

\section{f. Formula krim}

Formula sediaan krim ekstrak etanol daun mengkudu (Dewi, 2014) [8]

Tabel I. Formula krim daun mengkudu

\begin{tabular}{llll}
\hline Bahan & \multicolumn{3}{c}{ Jumlah } \\
\cline { 2 - 4 } & FI & FII & FIII \\
\hline Ekstrak Daun Mengkudu & $5 \%$ & $10 \%$ & $15 \%$ \\
Asam stearat & 4.0 & 4.0 & 4.0 \\
Setil alkohol & 3.0 & 3.0 & 3.0 \\
Metil paraben & 0.1 & 0.1 & 0.1 \\
Propil paraben & 0.05 & 0.05 & 0.05 \\
Sorbitol monostearat & 0.3 & 0.3 & 0.3 \\
Sorbitol 70\% & 3.0 & 3.0 & 3.0 \\
Polisorbat 60 & 2.7 & 2.7 & 2.7 \\
Aquades ad & 100 & 100 & 100 \\
\hline
\end{tabular}

\section{g. Uji Sifat Fisik Krim \\ Uji Organoleptis}

Pemeriksaan uji organoleptis perlu dilakukan untuk mengetahui kondisi krim yang dilakukan pengamatan terhadap warna, bau, dan bentuk krim yang telah dibuat.

\section{Uji Homogenitas}

Cara pada pengujian homogenitas dilakukan dengan cara mengambil $1 \mathrm{~g}$ krim ekstrak daun mengkudu pada bagian atas, bawah dan tengah kemudian dioleskan pada kaca transparan atau pada objek glass. Kemudian diamati jika terjadi pemisahan fase. 


\section{Uji pH}

Krim ekstrak daun mengkudu ditimbang sebanyak $1 \mathrm{~g}$ dan diencerkan dengan $10 \mathrm{~mL}$ aquades. Setelah mencapai kestabilan kemudian catat dan mengukur dengan menggunakan $\mathrm{pH}$ meter.

\section{Uji Daya Sebar}

Ditimbang krim ekstrak daun mengkudu sebanyak 0,5 g. Diletakkan ditengah kaca bulat dan meletakkan kaca yang satunya diatas masa krim. Biarkan selama satu menit. Kemudian diukur diameter yang menyebar lalu mengulanginya kembali dengan penambahan beban $50 \mathrm{~g}$ setiap satu menit.

Uji Daya Lekat

Timbang krim ekstrak daun mengkudu sebnayak $1 \mathrm{~g}$, diletakkan diatas gelas objek, lalu ditutup dengan objekglass lain. Kemudian ditekan dengan beban $1 \mathrm{~kg}$ selama 5 menit. Memasang alat uji pada objek glaass dan dilepas beban seberat $80 \mathrm{~g}$ [9].

\subsection{Analisis Data}

Analisis data uji total fenol dan total flavonoid menggunakan regesi linier serta analisis data daya sebar, $\mathrm{pH}$, dan daya lekat krim dilakukan menggunakan prog SPSS. Uji homogenitas dan normalitas dilakukan dengan uji One Way Anova Kemudian dilanjutkan uji non parametric dengan menggunakan analisis statistic Kruskal Wallis dan Mann-Whitney dengan menggunakan SPSS.

\subsection{Determinasi}

\section{HASIL DAN PEMBAHASAN}

Determinasi daun mengkudu (Morinda citrifolia L.) yaitu merupakan bagian yang penting dalam penelitian ini. Determinasi dilakukan dengan cara menyesuaikan ciri morfologi dari tanaman daun mengkudu terhadap kepustakaannya. Determinasi tanaman dilakukan di Laboratorium Ekologi Dan Biosistematik Departemen Biologi Fakultas Sains Dan Matematika Universitas Diponegoro.

\subsection{Pembuatan Simpisia}

Pada pembuatan simplisia digunakan bahan baku yaitu daun mengkudu setengah tua yang diperoleh dari daerah Sumurejo Kabupaten Semarang. Sebelum dibuat serbuk terlebih dahulu mengumpulkan daun mengkudu dan disortasi basah. Kemudian daun mengkudu dicuci, setelah dicuci kemudian dipotong kecil- kecil $\pm 2 \mathrm{~cm}$. Setelah itu daun mnegkudu dijemur dibawah sinar matahari dan ditutup dengan menggunakan kain hitam, agar zat aktif didalam daun mengkudu tidak hilang. Kemudian simplisia kering diserbuk dengan menggunakan blender dengan tujuan supaya ukuran simplisiannya sama sehingga memeprmudah migasi dari zat aktif ketika proses maserasi [10]. Hasil warna simplisia yang diperoleh yaitu coklat kehijauan serta serbuk diperoleh wrana hijau segar.

\subsection{Ekstrak Daun Mengkudu}

Hasil rendemen ekstrak daun mengkudu menghasilkan rendemen ekstrak sebanyak $3,2 \% \mathrm{~b} / \mathrm{b}$. Pada proses maserasi ini sangat menguntungkan karena dengan cara perendaman. Pembuatan ekstrak daun mengkudu ini pelarut yang digunakan adalah etanol $96 \%$ karena pelarut ini sangat efektif untuk mendapatkan kandungan senyawa flavonoid didalam daun mengkudu [11].

Pada proses maserasi dilakukan proses remaserasi karena ada senyawa yang tertinggal atau belum tersektraksi adanya senyawa yang tertinggal dikarenakan pelarut yang digunakan untuk mengestraksi telah mencapai titik jenuh.

\subsection{Total Fenol}

Pada uji kuantitatif penetapan kadar total fenol digunakan dengan metode folin ciocalteu. Metode ini adalah metode yang paling umum digunakan, dan juga paling sederhana yang dapat menentukan kandungan fenolik total dalam tanaman. 
Metode folin ciocalteu merupakan metode pereaksi reaksi organik yang dapat membentuk larutan kompleks pada senyawa fenolik yaitu molybdenum tungstat yang dapat membentuk warna biru. Semakin besar konsentrasi senyawa fenolik maka semakin banyak senyawa ion fenolat yang akan mereduksi asam heteropoli (fosfomolibdat-fosfotungstat) yang akan menjadi senyawa kompleks molybdenum-tugstat sehingga warna biru yang dihasilkan semakin bewarna pekat [12]. Reaksi terbentuknya ion fenolat berasal dari disosiasi proton senyawa fenolik, dimana reaksi tersebut hanya dapat terjadi dalam kondisi basa, sehingga dalam penelitian ini digunakan $\mathrm{Na}_{2} \mathrm{CO}_{3} 7,5 \%$ sebagai basa.

Pada penetapan kadar total fenolik dengan menggunakan spektrofotometri UV-Vis dengan menggunakan asam galat sebagai standarnya. Berdasarkan hal tersebut kurva standar yang digunakan adalah $300 \mathrm{ppm}$ serta diperoleh persamaan regesi linier yaitu $\mathrm{y}=0,014 \mathrm{x}-0,065$ serta hasil rata-rata yang diperoleh kadar total fenol yaitu 64,9 mgGAE/g dengan koefisien korelasi ( $\mathrm{r}$ ) 0,997 yang memenuhi syarat kelayakan metode analisis, yang dapat ditunjukkan pada gambar 1 .

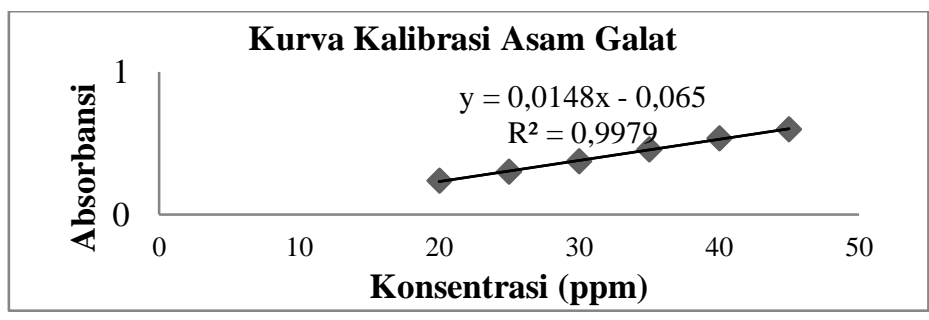

\section{Gambar 1. Kurva baku asam galat pada panjang gelombnag $760 \mathrm{~nm}$}

\subsection{Total Flavonoid}

Pada uji kuantitatif senyawa flavonoid dengan menggunakan metode $\mathrm{AlCl}_{3}$, yang mempunyai prinsip yaitu pembentukan kompleks yang stabail dengan C-4 gugus keto, serta pada C-3 atau C-5 gugus hidroksil dari flavon dan flavonol [13].

Pada penelitian kadar total flavonoid ini senyawa yang digunakan sebagai larutan standar adalah kuersetin, karena kuersetin merupakan flavonoid golongan flavonol yang memiliki gugus keto pada C-4 atau C-5 yang bertetangga dari flavon dan flavonoid [14].

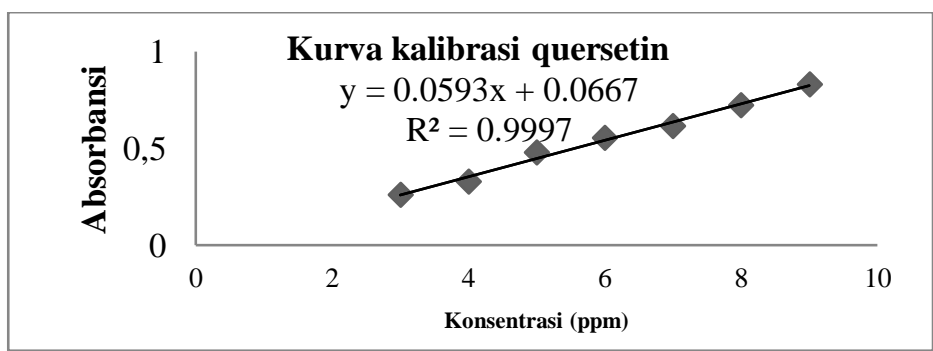

Gambar 2. Kurva baku kuersetin flavonoid

Berdasarkan hal tersebut kurva standar yang digunakan adalah $300 \mathrm{ppm}$ serta diperoleh persamaan regesi linier yaitu $y=0,0593 x+0,0667$ serta hasil rata rata total flavonoid diperoleh sebesar 0,219\% mgQE/g dengan koefisien korelasi (r) 0,9997 yang memenuhi syarat kelayanan metode analisis, yang dapat ditunjukkan pada Gambar 2.

\subsection{Kolerasi Fenol dan Flavonoid}

Berdasarkan hasil korelasi total fenol dan total flavonoid diperoleh hasil korelasi kadar total fenol dan antioksidan yaitu sebesar 99,96\%, sedangkan korelasi kadar total flavonoid dengan aktivitas antioksidan sebesar 99,96\%. Hal ini ditunjukkan dengan hasil korelasi kadar total fenol dan atioksidan yaitu dengan nilai $99,96 \%$ yang artinya memiliki nilai korelasi sangat kuat dan dapat dilihat pada gambar 3 . 


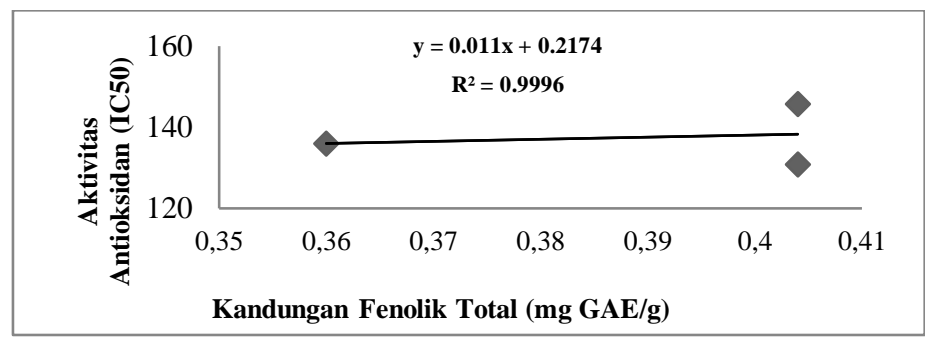

Gambar 3. Korelasi antara fenol dan antioksidan

Sedangkan korelasi kadar total flavonoid dengan aktivitas antioksidan sebesar 99,96\% yang mana jika terdapat korelasi positif artinya ada keterkaitan hubungan antara kadar total fenolik dengan kadar total flavonoid terhadap aktivitas antioksidan $\left(\mathrm{IC}_{50}\right)$ dan mempunyai nilai korelasi yang sangat kuat. Yang dapat dilihat pada gambar 4.

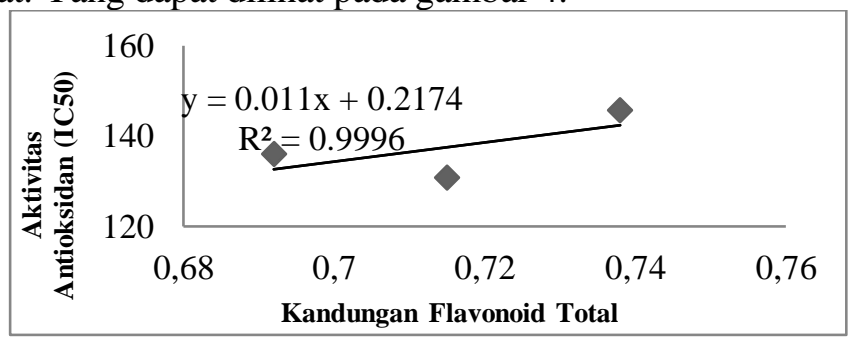

Gambar 4. Korelasi antara flavonoid dan antioksidan

\subsection{Pembuatan Sediaan Krim}

Bahan-bahan krim tipe minyak meliputi asam stearat, setil alcohol, propel paraben dan sorbitanmonostearat (fase 1) dicampurkan kedalam cawan lalu dipanaskan diatas waterbath dengan suhu $80^{\circ} \mathrm{C}$ hingga mencair. Metil paraben, larutan sorbitol70\%, polisorbat 60 (fase II) diarutkan dalam aquades yang telah dipanaskan pada suhu $80^{\circ} \mathrm{C}$ dalam beaker glass. campuran fase air tersebut diaduk hingga larut sempurna dengan menggunakan batang pengaduk. Kemudian campuran fase minyak dan fase air dimasukkan kedalam mortar dan diaduk sampai homogen. Kemudian ekstrak daun mengkudu dimasukkan kedalam basis tersebut pada suhu $45^{\circ} \mathrm{C}$ kemudian dibiarkan pada suhu kamar. Krim yang sudah jadi dimasukkan kedalam wadah yang sesuai.

\subsection{Uji Sifat Fisik Krim Uji Organoleptis}

Uji organoleptik yaitu salah satu bentuk spesifikasi untuk produk jadi dari sediaan semipadat yaitu sediaan krim. Uji organoleptik merupakan pengujian yang sangat subjektif [15].

Hasil pada pengujian organoleptis diperoleh dengan warna yang berbeda yaitu pada FI warna hijau pekat, FII hijau kecoklatan, FIII coklat pekat, basis dengan warna putih. Serta bau, bentuk dan tekstur krim diperoleh dengan hasil yang sama yaitu harum, lembut dan bentuk khas krim.

\section{Uji Homogenitas}

Pada uji homogenitas bertujuan untuk mengetahui serta melihat tercampurnya bahanbahan sediaan krim ekstrak daun mengkudu yang akan dibuat. Hasil yang diperoleh uji homogenitas pada basis, FI, FII, dan FIII menunjukkan hasil yang homogen. Hasil yang didapat pada uji homogenitas krim daun mengkudu tidak terdapat gumpalan-gumpalan. Hal ini diduga karena sifat zat aktif dari ekstrak daun mengkudu yaitu flavonoid mudah tercampur dengan basis A/M sehingga tidak terjadi pemisahan atau penggumpalan fasenya.

\section{Uji pH}

Hasil dari pengujian pH krim ekstrak daun mengkudu baik FI, FII, dan FIII dan basis yang dibuat yaitu memiliki pH 5 yang dapat dilihat pada gambar 5. Sehingga telah sesuai dengan pH fisiologis manusia yaitu berkisar 4,5-6,5. (Standar Nasional Indonesia (SNI) 16-4399-1996, 1996) [16]. Apabila krim memiliki pH terlalu basa maka dapat menyebabkan kulit akan bersisik dan dapat mengiritasi kulit. 
Hasil uji statistik menunjukkan bahwa data tidak terdistribusi normal $(\mathrm{P}<0,05)$ dan tidak homogen $(\mathrm{P}<0,05)$. Sehingga dilanjutkan dengan uji Mann-Whitney dan Kruskall Wallis untuk mengetahui perbedaan antara masing-masing kelompok yang menunjukkan hasil yang signifikan. Hasil uji Kruskall Wallis menunjukkan hasil tidak ada perbedaan yang signifikan antara basis, formula I, formula II, dan Formula III $(\mathrm{P}>0,05)$. Pada hasil uji Mann-Whitney menunjukkan hasil tidak ada perbedaan yang ditunjukkan oleh kelompok basis dengan formula I, formula II, dan formula III. Hal ini menunjukkan bahwa komposisi dan jumlah konsentrasi ekstrak dalam sediaan krim tidak mempengaruhi nilai $\mathrm{pH}$ sediaan krim.

\section{Uji Daya Sebar}

Dari hasil penelitian uji daya sebar yang dilakukan mendapatkan hasil uji daya sebar yaitu pada basis $(5 \mathrm{~cm})$, FI $(5 \mathrm{~cm})$, FII $(5,5 \mathrm{~cm})$, dan FIII $(6 \mathrm{~cm})$, yang dapat dilihat pada gambar 5 dimana daya sebar tersebut telah memenuhi syarat daya sebar sediaan semi padat yang baik yaitu sekitar $5-7 \mathrm{~cm}$.

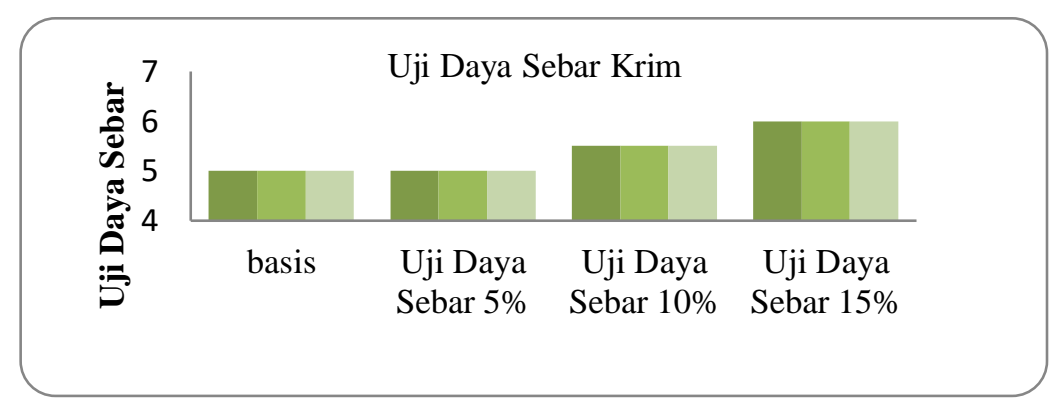

Gambar 5. Gafik Uji Daya Sebar

Pada kemampuan penyebaran krim yang baik akan memberikan kemudahan untuk diaplikasikan dipermukaan kulit yang sakit. Persyaratan untuk uji daya sebar yang baik atau sediaan topikal yaitu sekitar 5-7 cm [17]. Pada hasil uji statistik menunjukkan bahwa data tidak terdistribusi normal dan tidak homogen $(\mathrm{P}<0,05)$. Hasil uji Kruskall Wallis menunjukkan nilai $(\mathrm{P}<0,05)$ artinya bahwa ada perbedaan yang signifikan antara formula I, formula II, dan fomula III. Pada uji Mann-Whitney menunjukkan nilai $(\mathrm{P}<0,05)$ terdapat perbedaan yang signifikan antara basis, FI, FII, dan FIII yang artinya penambahan jumlah konsentrasi ekstrak yang berbedabeda pada tiap formula menyebabkan nilai daya sebar semakin meningkat tiap formula.

\section{Uji Daya Lekat Krim}

Hasil uji daya lekat yang telah dilakukan pada masing masing konsentrasi dan basis mempunyai daya lekat yang baik yaitu pada basis (5,33detik), FI (5,67detik), FII (6detik), dan FIII (6,33detik), sehingga ketiga formula memiliki kemampuan daya lekat yang baik yaitu tidak kurang dari 4detik.

Pada uji daya lekat persyaratan uji yang baik untuk sediaan krim atau sediaan topikal yaitu tidak kurang dari 4detik [17]. Hasil uji statistik menunjukkan bahwa data terdistribusi normal $(\mathrm{P}>0,05)$ dan data homogen $(\mathrm{P}>0,05)$, sehingga dilanjutkan dengan uji One Way Annova. Dari FI, FII, dan FIII tidak ada perbedaan yang signifikan ( $>>0,05)$, artinya bahwa konsentrasi ekstrak tidak mempengaruhi daya lekat sediaan krim.

\subsection{Uji Aktivitas Ekstrak dan Krim Antioksidan}

Pada uji kuantitaif untuk mengetahui aktivitas antioksidan dilakukan pengujian aktivitas antioksidan dengan menggunakan metode penangkapan radikal bebas dengan DPPH (1,1-difenil2-pikrilhidrazil). Metode pengujian antioksidan dengan menggunakan DPPH adalah jenis metode yang paling umum digunakan untuk menguji aktivitas antioksidan sampel secara invitro dan juga metode yang paling sederhana, cepat, serta bahan kimia dan smapel yang digunakan hanya sedikit, dan juga pengujian ini metode yang paling akurat [18].

Senyawa aktivitas antioksidan akan bereaksi dengan radikal DPPH melalui mekanisme donasi atom hydrogen dan menyebabkan terjadinya peluruhan warna DPPH dari ungu ke kuning yang diukur pada panjang gelombang $517 \mathrm{~nm}$ [19]. Antioksidan merupakan aktivitas suatu senyawa atau ekstrak untuk menghambat reaksi oksidasi yang dapat dinyatakan dengan presentase inhibisi. 
Parameter yang digunakan untuk menunjukkan aktivitas antioksidan adalah nilai harga Inhibition Concentration $\left(\mathrm{IC}_{50}\right.$ ). Senyawa antioksidan dikatakan sebagai antioksidan yang sangat kuat apabila nilai Inhibitory concentration of $50 \%\left(\mathrm{IC}_{50}\right)$ adalah kurang dari $50 \mathrm{mg} / \mathrm{L}$, antioksidan dikatakan kuat apabila nilai $\mathrm{IC}_{50} 50-100 \mathrm{mg} / \mathrm{L}$, sedang apabila nilai $\mathrm{IC}_{50} 100-150 \mathrm{mg} / \mathrm{L}$, lemah apabila nilai $\mathrm{IC}_{50}$ antara $150-200 \mathrm{mg} / \mathrm{L}$, serta antioksidan dikatakan sangat lemah bila nilai $\mathrm{IC}_{50}$ lebih dari 200mg/L [20, 21].

\section{Tabel II. IC 50 $_{\text {Kuersetin dan Ekstrak }}$}

\begin{tabular}{lc}
\hline \multicolumn{1}{c}{ IC $\mathbf{5 0}$} & Hasil Rata-Rata \\
\hline Kuersetin & $2,56 \mu \mathrm{g} / \mathrm{mL}$ \\
Esktrak Daun Mengkudu & $137,527 \mu \mathrm{g} / \mathrm{mL}$ \\
Formula Krim 5\% & $124,724 \mu \mathrm{g} / \mathrm{mL}$ \\
Formula Krim 10\% & $123,333 \mu \mathrm{g} / \mathrm{mL}$ \\
Formula Krim 15\% & $123,286 \mu \mathrm{g} / \mathrm{mL}$ \\
\hline
\end{tabular}

Hasil yang diperoleh aktivitas antioksidan kuersetin memiliki aktivitas antioksidan yang sangat kuat dengan alasan karena kuersetin merupakan golongan flavonoid golongan flavonol yang mempunyai gugus keto pada $\mathrm{C}-4$ atau $\mathrm{C}-5$ yang bertetangga dari flavon dan flavonoid [14]. Nilai Inhibition Concentration 50\% ( $\mathrm{IC}_{50}$ ) kuersetin standar didapatkan hasil rata rata nilai $\mathrm{IC}_{50}$ kuersetin sebesar $2,56 \mu \mathrm{g} / \mathrm{ml}$, yang dapat dilihat pada tabel II. Dibandingkan dengan nilai Inhibition Concentration 50\% ( $\mathrm{IC}_{50}$ ) esktrak etanol daun mengkudu (Morinda citrifolia L.) diperoleh hasil rata-rata sebesar $137,527 \mathrm{~g} / \mathrm{ml}$, serta dibandingkan dengan nilai $\mathrm{IC}_{50}$ pada formula krim konsentrasi $5 \%$ diperoleh rata-rata sebesar $124,724 \mu \mathrm{g} / \mathrm{mL}$, formula krim konsentrasi $10 \%$ diperoleh rata-rata $\mathrm{IC}_{50}$ sebesar $123,333 \mu \mathrm{g} / \mathrm{mL}$, serta nilai $\mathrm{IC}_{50}$ formula krim $15 \%$ diperoleh hasil rata-rata sebesar $123,286 \mu \mathrm{g} / \mathrm{mL}$ yang artinya tergolong memiliki nilai aktivitas antioksidan yang sedang yaitu dengan nilai $\mathrm{IC}_{50}(100-150 \mathrm{mg} / \mathrm{L})$. Semakin kecil nilai $\mathrm{IC}_{50}$ maka nilai aktivitas antioksidanya semakin besar atau kuat. Hasil data $\mathrm{IC}_{50}$ esktrak dank rim dapat dilihat pada tabel II.

Hasil uji statistik menunjukkan bahwa Pada ekstrak, formula I, formula II dan formula III, ada perbedaan yang signifikan ( $\mathrm{p}<0,05)$. Begitu juga dengan kuersetin memiliki nilai $(\mathrm{p}<0,05)$ yaitu ada perbedaan yang signifikan. Hal ini menunjukkan bahwa setiap nilai aktivitas antioksidan pada krim tidak sama dengan kuersetin. Jika semakin kecil nilai $\mathrm{IC}_{50}$ maka pengaruh aktivitas antioksidan semakin besar.

\section{KESIMPULAN}

Berdasarkan hasil penelitian dapat disimpulkan bahwa, kadar total fenol pada daun mengkudu 64,9mgGAE/g. Kadar total flavonoid ekstrak daun mengkudu sebesar $0,219 \% \mathrm{mgQE} / \mathrm{g}$. Ekstrak daun mengkudu memiliki aktivitas antioksidan dengan nilai 137,527 $\mu \mathrm{g} / \mathrm{mL}$. Formula krim ekstrak daun mengkudu mempunyai sifat fisik yang baik (memenuhi syarat SNI, dan kriteria yang baik). Aktivitas antioksidan dari krim esktrak daun mengkudu pada FI (5\%) yaitu $\mathrm{IC}_{50} 124,724$, FII (10\%) IC $_{50} 123,333$ dan FIII(15\%) IC 50 121,28.

\section{DAFTAR PUSTAKA}

[1] Sari, A. N, Antioksidan Alternatif Untuk Menangkal Bahaya Radikal Bebas Pada Kulit. Journal of Islamic Scienc and Technology, 1(1), 63-68, 2015 [Online], https://doi.org/10.1016/j.solmat.2013.03.040

[2] Werdhasari, A, Peran Antioksidan Bagi Kesehatan. Jurnal Biotek Medisiana Indonesia, Vol.3.2, 59-68, 2014.

[3] Pham-Huy, L. A., He, H., \& Pham-Huy, C, Free Radicals, Antioxidants In Disease And Health. International Journal of Biomedical Science, 4(2), 89-96, 2008 [Online], https://doi.org/10.1073/pnas.0804252105 
[4] Suwarni, E., Cahyaningsih, E., \& Yuda, P. E. S. K, Uji Efek Analgesik Infusa Daun Mengkudu (Morinda citrifolia L.) Pada Mencit Jantan (Mus musculus). Medicamento, 2, 611, 2016.

[5] Serafini, M. R., Detoni, C. B., Menezes, P. D. P., Pereira Filho, R. N., Fortes, V. S., Vieira, M. J. F., ... Araújo, A. A. D. S, UVA-UVB Photoprotective Activity of Topical Formulations Containing Morinda citrifolia Extract. BioMed Research International, 2014 [Online], https://doi.org/10.1155/2014/587819

[6] Herlina, S, Efektivitas Ekstrak Daun Mengkudu (Morinda citrifolia) untuk Meningkatkan Respon Imun Non Spesifik dan Kelangsungan Hidup Ikan Mas (Cyprinus carpio) Juni, 6(1), 4, 2017.

[7] Sharon, N., \& Anam, S, Formulasi Krim Antioksidan Ekstrak Etanol Bawang Hutan (Eleutherine palmifolia L. Merr), 02, 111-122, 2013.

[8] Dewi, R, Uji Stabilitas Fisik Formula Krim yang Mengandung Ekstrak Kacang Kedelai ( Glycine max ). Kefarmasian, 1(3), 194-208, 2014.

[9] Ikhsanudin, A, Formulation Of Vanishing Cream Sereessential Oil (Cymbopogon citratus (DC) Stapf) And Physical Properties Aalso Repellant Activity Testing Againts Female Aedes aegypti Mosquitoes. 2011, 01, 81-91, 2011.

[10] Mayasari, U., \& Laoli, M. T, Karakterisasi Simplisia Dan Skrining Fitokimia Daun Jeruk Lemon ( Citrus limon ( L .) Burm . f .), 2(1), 7-13, 2018.

[11] Lestari, T., Nurmala, A., \& Nurmalasari, M, Penetapan Kadar Polifenol Dan AKtivitas Antibakteri Ekstrak Etanol Daun Sintrong (Crassocephalum crepidiodes (Benth.) S. moore). Jurnal Kesehatan Bakti Tunas Husada, 13, 213-227, 2015.

[12] Lestari, D. M., Mahmudati, N., Sukarsono, S., Nurwidodo, N., \& Husamah, H, Aktivitas Antioksidan Ekstrak Fenol Daun Gayam (Inocarpus fagiferus Fosb). Biosfera, 35(1), 37, 2018 [Online], https://doi.org/10.20884/1.mib.2018.35.1.596

[13] Haeria, Hermawati, \& Dg.Pine, A. T. U, Penentuan Kadar Flavonoid Total dan Aktivitas Antioksidan Ekstrak Etanol Daun Bidara (Ziziphus spina-christi L.). Journal of Pharmaceutical and Medicinal Sciences, 1(2), 57-61, 2016.

[14] Aminah, Tomayahu, N., \& Abidin, Z, Penetapan Kadar Flavonoid Total Ekstrak Etanol Kulit Buah Alpukat ( Persea americana Mill .) Dengan Metode Spektrofotometri UV-Vis. Fitofarmaka Indonesia, 4(2), 226-230, 2016.

[15] NSP, A. S., Mufrod, \& Purwanto, Aktivitas Antioksidan Krim Sari Tomat( Solanum lycopersicum L .), 18(September), 132-140, 2013.

[16] Standar Nasional Indonesia (SNI) 16-4399-1996. (1996). Sediaan Tabir Surya.

[17] Ulaen, S. P. J., Banne, Y., \& Suatan, R. A, Pembuatan Salep Anti Jerawat dari Ekstrak Rimpang Temulawak (Curcuma xanthorhiza roxb). Jurnal Kesehatan Politeknik Kesehatan, 1, 45-49, 2012.

[18] Raudhotul, S., Ifaya, M., Pusmarani, J., \& Nurhikma, E, Uji Aktivitas Antioksidan Ekstrak Metanol Kulit Pisang Raja ( Musa Paradisiaca sapientum ) Dengan Metode DPPH ( 2 , 2 Difenil-1-Pikrilhidrazil ). Jurnal Mandala Pharmacon Indonesia, 04(July), 1 06, 2018.

[19] Ekowati, D., \& Ningsih, D, Formulation of Morinda citrifolia L. Fruits Extract as Antioxidant Cream. 2014, 11, 46-53, 2014

[20] Molyneux, P, The use of the stable free radical diphenylpicryl-hydrazyl (DPPH) for estimating antioxidant activity. Songklanakarin Journal of Science and Technology, 26(December 2003), 211-219, 2004 [Online], https://doi.org/10.1287/isre.6.2.144

[21] Salsabila, N., Indratmoko, S., \& o, A. T. N. L., Pengembangan Hand \&amp; Body Lotion Nanopartikel Kitosan dan Spirulina Sp sebagai Antioksidan. Jurnal Ilmiah JOPHUS : Journal Of Pharmacy UMUS, 2(01), 11-20, 2020 [Online], https://doi.org/10.46772/jophus.v2i01.268 